\title{
Successful switch to tenofovir after suboptimal response to entecavir in an immunocompromised patient with chronic hepatitis $B$ and without genotypic hepatitis $B$ virus resistance
}

\author{
C. Sarrecchia $\cdot$ V. Svicher $\cdot$ A. Volpi $\cdot$ \\ R. Salpini $\cdot$ L. Ceccarelli $\cdot$ P. Sordillo . \\ A. Bertoli $\cdot$ C. F. Perno $\cdot$ M. Andreoni
}

Received: 18 October 2010/ Accepted: 31 May 2011

(C) Springer-Verlag 2011

\begin{abstract}
We report a case of an immunocompromised patient affected by chronic hepatitis B virus (HBV) with high basal HBV viremia ( $>8 \log _{10} \mathrm{IU} / \mathrm{ml}$ ) who failed an entecavir regimen, despite the absence of primary or secondary drug resistance mutations. The patient achieved sustained virological success (serum HBV DNA $<12$ IU/ $\mathrm{ml}$ ) when tenofovir was added to the treatment. This case highlights the difficulty in choosing an optimal therapy in such specific conditions and supports the concept of tailoring therapy (including combination regimens) on the basis of the particular conditions of each individual patient.
\end{abstract}

Keywords Hepatitis B - Entecavir - Drug resistance · Immunocompromised · Therapy

\section{Introduction}

Besides interferon, five nucleos(t)ide DNA polymerase inhibitors (LMV, lamivudine; ETV, entecavir; TBV, telbivudine; ADV, adefovir; and TDF, tenofovir) have been approved for the treatment of chronic hepatitis $\mathrm{B}$ virus (HBV) infection. They can efficiently suppress HBV replication in most patients and delay disease progression. Unfortunately, when antiviral therapy fails to be fully suppressive, new viral variants emerge, allowing HBV to

C. Sarrecchia $(\bowtie) \cdot$ A. Volpi · L. Ceccarelli · P. Sordillo

M. Andreoni

Department of Public Health, University of Rome "Tor

Vergata", Rome, Italy

e-mail: sarrecchia@med.uniroma2.it

V. Svicher · R. Salpini - A. Bertoli · C. F. Perno Department of Experimental Medicine and Biochemical Science, University of Rome "Tor Vergata", Rome, Italy become resistant to one or more drugs by accumulating mutations, either alone or in clusters. The emergence of drug resistance has been associated with a decreased rate of $\mathrm{HBeAg}$ seroconversion, reversion of histologic improvement, an increased rate of disease progression, and severe exacerbations in patients with cirrhosis [1-3].

To date, entecavir and tenofovir are considered to be the most potent anti-HBV drugs with the highest genetic barrier to resistance. In particular, treatment with entecavir has been associated with a mean reduction in serum HBV DNA levels from baseline to week 48 of $6.9 \mathrm{log}$ in $\mathrm{HBeAg}$ positive patients and $5.0 \mathrm{log}$ in $\mathrm{HBeAg}$-negative patients $[4,5]$, and with a very low rate $(1.2 \%)$ of drug resistance emergence after 5 years of treatment [6]. In the case of partial virological response to entecavir treatment (despite full adherence), some experts suggest adding tenofovir to rapidly suppress viral replication and prevent the emergence of drug resistance [7].

Tenofovir disoproxil fumarate (TDF) is a highly potent drug active against a broad spectrum of viral infections, including human immunodeficiency virus (HIV-1) and HBV [8]. Recently, its high potency and lasting antiviral effect were confirmed by two randomized trials, mostly in treatment-naive HBV monoinfected, HBeAg-positive, and HBeAg-negative patients [9]. Due to their high efficacy, entecavir and tenofovir are recommended as first-line drugs by the current guidelines.

Viral hepatitis has become a significant concern, especially in patients with hematological malignancies, because of the risk of HBV reactivation in severe immunodeficiency conditions, both directly related to malignant disease and/or immunosuppressive therapy. In these conditions, the use of drugs with high potency and high genetic barrier to resistance, such as entecavir or tenofovir, is advisable. 


\section{Case presentation}

A 29-year-old Caucasian woman, affected by bone marrow aplasia since 1999, was first seen at the Department of Haematology of Tor Vergata University Hospital, Rome, Italy, in July 2007 for clinical and immunovirological assessment prior to bone marrow transplantation. At the time of pre-transplantation virological screening, she tested positive for $\mathrm{HBsAg}, \mathrm{HBeAg}$, and anti-HBc, and negative for hepatitis D virus (HDV), hepatitis C virus (HCV), and HIV antibodies. She presented with HBV DNA $>110,344,828 \mathrm{IU} / \mathrm{ml}\left(>8.04 \log _{10} \mathrm{IU} / \mathrm{ml}\right)$ and elevated serum alanine aminotransferase (ALT) level $(60 \mathrm{IU} / \mathrm{ml})$. The genotypic analysis of HBV revealed the presence of a completely wild-type virus, characterized by the A genotype and adw 2 serotype; neither primary nor secondary mutations potentially related to drug resistance were observed. However, the analysis of polymorphisms throughout the entire reverse transcriptase (RT) revealed the presence of rtL217R, which has been recently associated with a poor virological response to adefovir [10], while the analysis of the entire HBsAg revealed the presence of the amino acid asparagine (N) at HBsAg position 131. Asparagine is the wild-type amino acid at this position in the HBV A genotype $[9,11]$. The full blood count exhibited thrombocytopenia (platelet count $36,000 / \mu \mathrm{L}$ ), leukopenia (white blood cell [WBC] count $3,270 / \mathrm{mm}^{3}$ ), and mild anemia. Ultrasound examination of the liver was normal. In October 2007, oral entecavir treatment (ETV $-0.5 \mathrm{mg} /$ day) was initiated. The serum HBV DNA declined to 5,562 IU/ $\mathrm{ml}\left(3.75 \log _{10} \mathrm{IU} / \mathrm{ml}\right)$ at week 12 and to $2,986 \mathrm{IU} / \mathrm{ml}(3.48$ $\log _{10} \mathrm{IU} / \mathrm{ml}$ ) at week 24 , while the ALT level decreased to $45 \mathrm{IU} / \mathrm{ml}$ at week 12 without reaching normalization at week 24. In October 2008 (at week 48 of treatment), the patient experienced a further increase in the serum HBV DNA of $0.96 \mathrm{log}$, from the nadir value of $2,986 \mathrm{IU} / \mathrm{ml}$ (3.47 $\log _{10} \mathrm{IU} / \mathrm{ml}$ ) at week 24 to $27,190 \mathrm{IU} / \mathrm{ml}(4.43$ $\log _{10} \mathrm{IU} / \mathrm{ml}$ ) at week 48 . Only a slight decrease in the ALT level was observed (Fig. 1). A second genotypic test showed no viral evolution, confirming the absence of mutated HBV strains (the pattern observed before starting the therapy). The presence of both rtL217R and sT131N was confirmed in this and in all subsequent genotypic resistance tests performed during the therapeutic history of the patient. In addition, complete adherence to therapy was also confirmed. In January 2009, at week 60 of entecavir monotherapy, the serum HBV DNA level remained almost stable at 20,366 IU/ml. Even if we cannot exclude technical deviation of the assay for serum HBV DNA quantification, this value supports persistent active viral replication; hence, tenofovir $(245 \mathrm{mg} /$ day $)$ was added to the entecavir regimen.
The combination therapy caused a drop in the serum HBV DNA to $<12 \mathrm{IU} / \mathrm{ml}$ (limit of detectability, TaqMan Analyzer, Roche), though the normalization of the ALT level did not occur until after 2 months (March 2009). In May 2009, after 16 weeks of combination therapy, the HBV DNA level was undetectable. As viral suppression was confirmed, tenofovir was discontinued, and entecavir monotherapy resumed. However, after 8 weeks, an increase in the serum HBV DNA to $230 \mathrm{IU} / \mathrm{ml}(2.36$ $\log _{10} \mathrm{IU} / \mathrm{ml}$ ) was observed. A third HBV genotypic resistance test was performed, still showing a wild-type genotypic profile without any evidence of viral genetic evolution. Combination therapy with entecavir and tenofovir was restarted (ETV $0.5 \mathrm{mg} /$ day + TDF $245 \mathrm{mg}$ / day), and, at week 12, the therapy resulted in a drop of serum HBV DNA to undetectable levels and normalization of the ALT level. At this time, entecavir was stopped and tenofovir continued. After 2 months of tenofovir monotherapy, the HBV DNA level was undetectable, at $<12 \mathrm{IU} / \mathrm{ml}$ (limit of detectability). After 32 weeks of tenofovir monotherapy, the HBV DNA level remained undetectable and the ALT level was normal.

\section{Discussion}

This case report highlights the problems concerning selection of the optimal therapeutic regimen in immunocompromised (IC) patients with a high level of basal HBV DNA.

The selection of a first-line antiviral agent should always consider both the characteristics of the patient's disease (HBeAg status, ALT level, HBV DNA level) and clinical conditions [12], and should aim to achieve a rapid and sustained drop in HBV DNA to undetectable levels. There is increasing evidence that a rapid drop in serum HBV DNA to levels below the limit of detection within the first 2 weeks is associated with a lower risk of clinical disease progression [13].

In this case, we observed a suboptimal response (even if still within the acceptable response) of entecavir monotherapy. Indeed, we noted an initial effectiveness of entecavir therapy, with a reduction of viremia from 8.04 $\log _{10} \mathrm{IU} / \mathrm{ml}$ at baseline to $3.48 \log _{10} \mathrm{IU} / \mathrm{ml}$ at week 24 , followed by a virological increase to $4.43 \log _{10} \mathrm{IU} / \mathrm{ml}$ at week 48 , despite the absence of genotypic drug resistance. The suppression of serum HBV DNA below the limit of detection (serum HBV DNA $<12 \mathrm{IU} / \mathrm{ml}$ ) was obtained only when tenofovir was added to the entecavir regimen.

The ability of tenofovir to suppress serum HBV DNA under immunosuppressive conditions is also consistent with a recently published clinical case of one HIV-infected, anti-HBc-positive individual who showed a severe 


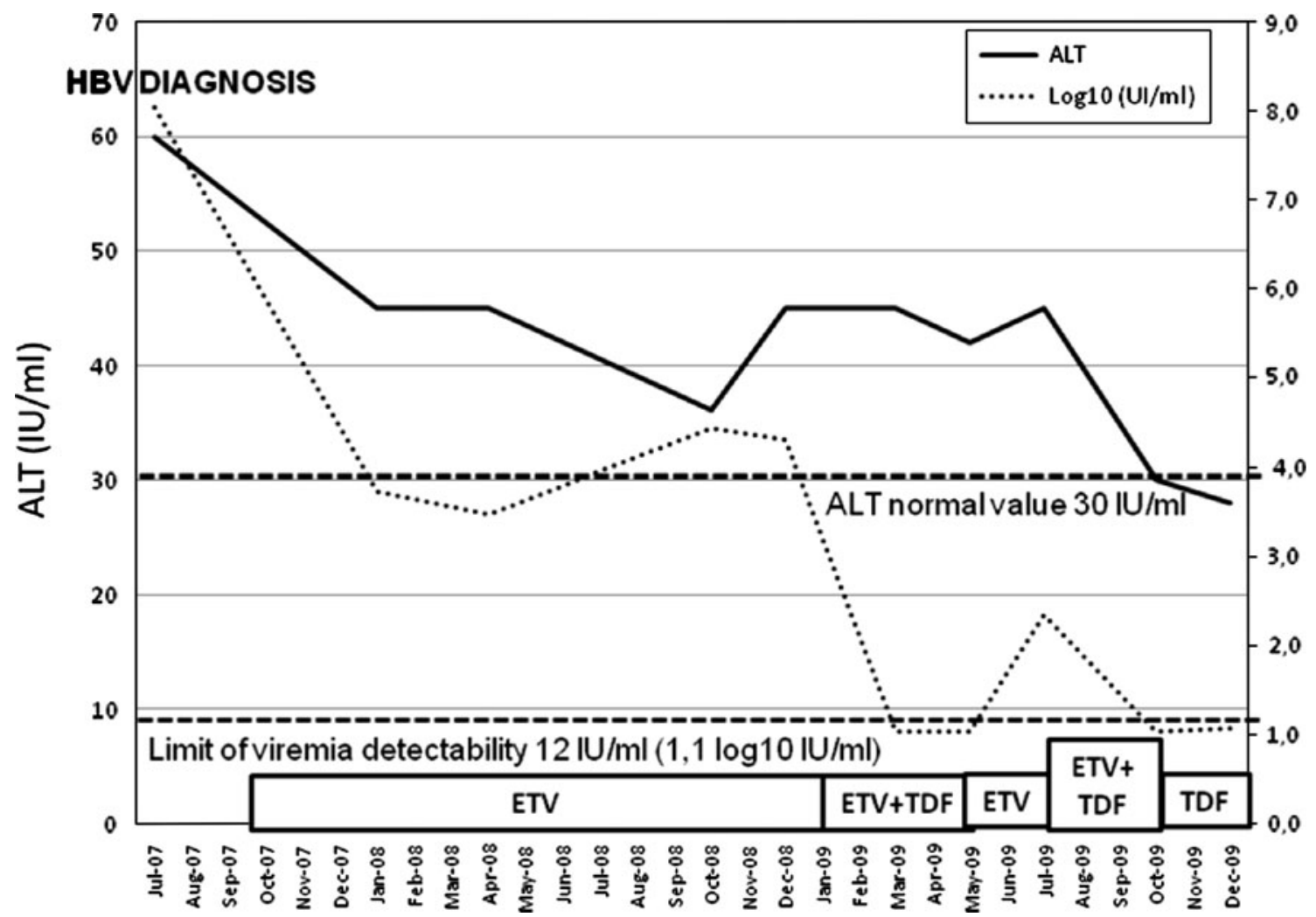

Fig. 1 Evolution of the serum hepatitis B virus (HBV) DNA and alanine aminotransferase (ALT) level during therapy with entecavir (ETV), $\mathrm{ETV}+$ tenofovir (TDF), and TDF

reactivation of $\mathrm{HBV}$ after the interruption of antiretroviral therapy (ART). In this patient, the serum HBV DNA level decreased dramatically after the subsequent introduction of tenofovir-based ART [14].

The role of the immune system in controlling HBV replication has also been highlighted in a recent study where the potential effect of the interruption and subsequent re-introduction of highly active antiretroviral therapy (HAART) on the frequency and dynamics of overt HBV infection in HIV-infected individuals was investigated [15]. Among the 29 HIV-infected individuals positive for anti-HBc and negative for HBsAg included in the study, nine $(31 \%)$ showed signs of overt HBV infection during the 100-week study period: three patients showed intermittent serum HBV DNA, while six patients were HBV DNA-positive only at 16 weeks following HAART resumption. The HBV DNA load invariably fell below the sensitivity of the quantitative test after the resumption of ART [15].

Of note, the analysis of the HBsAg revealed the presence of asparagine $(\mathrm{N})$ at position 131, naturally occurring in genotype A. This amino acid has been shown to reduce the HBsAg immunogenic surface by introducing a novel $\mathrm{N}$-linked glycosylation site [16]. Thus, it is conceivable that, in an immunocompromised patient, the presence of this amino acid can be sufficient to allow HBV evasion from the limited pressure imposed by the immune system, thus, further increasing viral replication. In such a particular context, the decision on the optimized management becomes more complicated, and it remains debated whether it is better the add-on combination strategy or the switch strategy. In this clinical case, the initial add-on of TDF to ETV followed by the complete switch to TDF results in long-term virological suppression. Overall, this result supports the need to tailor the therapy for each individual patient.

The suboptimal response to entecavir may also be related to the presence of a minority of drug-resistant strains (with a prevalence of $<15-20 \%$ of the overall viral quasispecies) not detected by the standard population sequencing based on the Sanger methodology. In fact, recent studies have demonstrated, by using highly innovative methodology based on ultra-deep sequencing, the existence of primary drug resistance mutations prior to treatment administration [13, 16, 17]. Those minority variants should have appeared as predominant species in plasma over long-term treatment with entecavir, while this is not the case in at least two genotypic tests performed during entecavir treatment. In addition, we cannot exclude the presence of polymorphisms in the HBV A genotype 
that can compromise the decay of serum HBV DNA during entecavir monotherapy. For instance, a recent study has shown the significant association of L217R, which is a typical polymorphism in HBV A genotype (subtype A2), with a poor virological response to adefovir [10]. It is conceivable that other, not yet defined, polymorphisms in HBV A genotype can compromise the virological response to entecavir treatment. Finally, the possibility cannot be excluded that reduced blood levels of entecavir (possibly due to limited drug absorption) made the drug unable to fully suppress the virus. In this case, exploring the use of entecavir (1 mg) may have provided ex juvantibus evidence of the need for increased dosing of entecavir.

In conclusion, this case shows the possibility of the suboptimal response of selected anti-HBV drugs (in this case, entecavir, but not tenofovir) in the absence of noted drug resistance mutations. The lack of virological success during monotherapy can be explained by the presence of an immune escape mutation and/or specific (not yet defined) polymorphisms in HBV retroviral therapy which are able to affect the virological response to drugs.

This case also suggests that, in particular settings, such as high basal viremia in an immunocompromised patient, the use of potent drugs alone or in combination should be evaluated in order to rapidly suppress viral replication and to lower the risk of disease progression. Due to the continuously increasing number of cases of iatrogenic immunosuppression in HBV-positive patients, prospective studies of large study populations are needed in order to confirm the effectiveness of this therapeutic strategy.

Consent The patient and the ethical committee of the hospital gave their approval for the anonymous publication of this clinical case.

Conflict of interest None.

\section{References}

1. Mutimer D, Dusheiko G, Barrett C, Grellier L, Ahmed M, Anschuetz G, Burroughs A, Hubscher S, Dhillon AP, Rolles K, Elias E. Lamivudine without HBIg for prevention of graft reinfection by hepatitis B: long-term follow-up. Transplantation. 2000;70:809-15.

2. Dienstag JL, Goldin RD, Heathcote EJ, Hann HW, Woessner M, Stephenson SL, Gardner S, Gray DF, Schiff ER. Histological outcome during long-term lamivudine therapy. Gastroenterology. 2003;124:105-17.

3. Yuen MF, Wong DK, Sablon E, Yuan HJ, Sum SM, Hui CK, Chan AO, Wang BC, Lai CL. Hepatitis B virus genotypes B and $\mathrm{C}$ do not affect the antiviral response to lamivudine. Antivir Ther. 2003;8:531-4.

4. Chang TT, Gish RG, De Man R, Gadano A, Sollano J, Chao YC, Lok AS, Han KH, Goodman Z, Zhu J, Cross A, DeHertogh D,
Wilber R, Colonno R, Apelian D; BEHoLD AI463022 Study Group. A comparison of entecavir and lamivudine for $\mathrm{HBeAg}$ positive chronic hepatitis B. N Engl J Med. 2006;354:1001-10.

5. Lai CL, Shouval D, Lok AS, Chang TT, Cheinquer H, Goodman Z, DeHertogh D, Wilber R, Zink RC, Cross A, Colonno R, Fernandes L; BEHoLD AI463027 Study Group. Entecavir versus lamivudine for patients with $\mathrm{HBeAg}$-negative chronic hepatitis B. N Engl J Med. 2006;354:1011-20.

6. Colonno RJ, Rose RE, Pokornowski K, Baldick CJ, Eggers B, $\mathrm{Xu}$ D, Cross A, Tenney DJ. Four year assessment of entecavir resistance in nucleoside naive and lamivudine refractory patients. J Hepatol. 2007;46:S294.

7. European Association for the Study of the Liver. EASL Clinical Practice Guidelines: management of chronic hepatitis B. J Hepatol. 2009;50:227-42.

8. Marcellin P, Heathcote EJ, Buti M, Gane E, De Man RA, Krastev Z, Germanidis G, Lee SS, Flisiak R, Kaita K, Manns M, Kotzev I, Tchernev K, Buggisch P, Weilert F, Kurdas OO, Shiffman ML, Trinh H, Washington MK, Sorbel J, Anderson J, Snow-Lampart A, Mondou E, Quinn J, Rousseau F. Tenofovir disoproxil fumarate versus adefovir dipivoxil for chronic hepatitis B. N Engl J Med. 2008;359:2442-55.

9. Chen CJ, Yang HI, Iloeje UH; REVEAL-HBV Study Group. Hepatitis B virus DNA Levels and outcomes in chronic hepatitis B. Hepatology. 2009;49:S72-84.

10. Rodriguez-Frias F, Jardi R, Schaper M, Buti M, Ferrer-Costa C, Tabernero D, Homs M, Esteban R. Adefovir for chronic hepatitis B treatment: identification of virological markers linked to therapy response. Antivir Ther. 2008;13:991-9.

11. Chen WN, Oon CJ. Hepatitis B virus surface antigen (HBsAg) mutants in Singapore adults and vaccinated children with high anti-hepatitis B virus antibody levels but negative for HBsAg. J Clin Microbiol. 2000;38:2793-4.

12. Khokhar A, Afdhal NH. Therapeutic strategies for chronic hepatitis B virus infection in 2008. Am J Med. 2008;121:S33-44.

13. Rodriguez C, Chevaliez S, Pallier C, Pawlotsky JM. Ultra-deep sequencing analysis demonstrates pre-existence of HBV resistance substitutions at baseline in patients who subsequently develop clinical resistance. In: Proceedings of the 17th Conference on Retroviruses and Opportunistic Infections (CROI 2010), San Francisco, CA, February 2010, paper \# 170LB.

14. Bagaglio S, Porrino L, Lazzarin A, Morsica G. Molecular characterization of occult and overt hepatitis B (HBV) infection in an $\mathrm{HIV}$-infected person with reactivation of $\mathrm{HBV}$ after antiretroviral treatment interruption. Infection. 2010;38:417-21.

15. Bagaglio S, Bianchi G, Danise A, Porrino L, Uberti-Foppa C, Lazzarin A, Castagna A, Morsica G. Longitudinal evaluation of occult Hepatitis B infection in HIV-1 infected individuals during highly active antiretroviral treatment interruption and after HAART resumption. Infection. 2011;39:121-6. Epub 2011 Mar 22.

16. Solmone M, Vincenti D, Prosperi MC, Bruselles A, Ippolito G, Capobianchi MR. Use of massively parallel ultradeep pyrosequencing to characterize the genetic diversity of hepatitis B virus in drug-resistant and drug-naive patients and to detect minor variants in reverse transcriptase and hepatitis B S antigen. J Virol. 2009;83:1718-26.

17. Margeridon-Thermet S, Shulman NS, Ahmed A, Shahriar R, Liu T, Wang C, Holmes SP, Babrzadeh F, Gharizadeh B, Hanczaruk B, Simen BB, Egholm M, Shafer RW. Ultra-deep pyrosequencing of hepatitis B virus quasispecies from nucleoside and nucleotide reverse-transcriptase inhibitor (NRTI)-treated patients and NRTInaive patients. J Infect Dis. 2009;199:1275-85. 